\title{
Physiological quality of pink pepper seeds (Schinus terebinthifolia Raddi) as a function of storage
}

\author{
Calidad fisiológica de las semillas de pimienta-rosa (Schinus terebinthifolia \\ Raddi) en función del almacenamiento
}

Thaísa de Oliveira Silveiraㄹ; Madelon Rodrigues Sá Braz²; Gilmara Pires de Moura Palermo³; Tiago Böer Breier ${ }^{4}$

\begin{abstract}
ARTICLE DATA
Researcher, Engenheira Agrônoma. Universidade Federal Rural do Rio de Janeiro. Rio de Janeiro, Brasil, thaiisa_oliveira@hotmail.com

2 Professor. Dr. - Universidade Federal Rural do Rio de Janeiro. Rio de Janeiro, Brasil, madelonsa@ hotmail.com

3 Professor. Dr. - Universidade Federal Rural do Rio de Janeiro. Rio de Janeiro, Brasil, gilpalermo@ hotmail.com

4 Professor. Dr. Universidade Federal Rural do Rio de Janeiro. Rio de Janeiro, Brasil, tiagobreier@ gmail.com
\end{abstract}

Cite: Silveira, T. O.; Braz, M. R. S.; Palermo, G. P. M.; Breier, T. B. (2021). Physiological quality of pink pepper seeds (Schinus terebinthifolia Raddi) as a function of storage. Revista de Ciencias Agrícolas. 38(1): 144-157. doi: https://doi.org/10.22267/rcia.213801.150

\section{Received: March 032020.}

Accepted: April 152021.

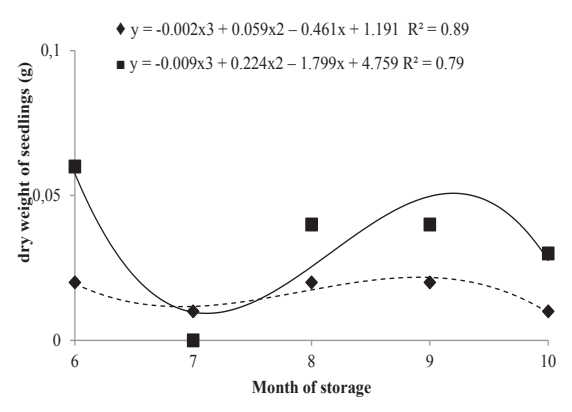

\section{ABSTRACT}

Seeds of native forest species for food and seedling production have a growing demand that impacts the need for studiesinvolving seed storage to maintain good levels of germination quality. Thus, scientific analyzes that explore the physiological potential of these seeds' species are necessary; especially for the pink pepper (Schinus terebinthifolia Raddi), a species used as an alternative source of income for traditional communities, and which has been arousing interest due to the consumption of its fruits as a condiment in the national and international market. This work aimed to assess the physiological quality of pink pepper seeds according to the storage period and seed size. The seeds come from a rural settlement, a pioneer in the extraction of pink pepper, in the state of Rio de Janeiro, Brazil. The seeds were evaluated for moisture content, germination, first count, length and dry weight of the germinated seedlings during the period of time that they remained stored, and the size of the seeds. The results allowed us to conclude that: i) the germinative percentage of the stored pink pepper seeds decreased over the months. ii) The moisture content of the seeds decreased over the evaluated months. iii) The different seeds' sizes did not show differences in germination and storage time, and iv) values of length and dry weight of the seedlings did not differ according to the period of storage.

Keywords: Storage; germination; conservation; physiological quality;agricultural settlement.

\section{RESUMEN}

Las semillas de especies forestales nativas para la producción de plántulas y alimentos tienen una demanda creciente que impacta la necesidad de estudios que involucren el almacenamiento de semillas para mantener buenos niveles de calidad de germinación. Así, son necesarios análisis científicos que exploren el potencial fisiológico de las semillas de estas especies, especialmente para la pimienta-rosa (Schinus terebinthifolia Raddi), especie utilizada como fuente alternativa de ingresos para las 
comunidades tradicionales y que ha despertado interés por la consumo de sus frutos como condimento en el mercado nacional e internacional. Este trabajo tuvo como objetivo evaluar la calidad fisiológica de las semillas de pimientarosa según el período de almacenamiento y el tamaño de la semilla. Las semillas provienen de un asentamiento rural, pionero en la extracción de pimienta rosa, en el estado de Río de Janeiro, Brasil. Las semillas fueron evaluadas por contenido de humedad, germinación, primer conteo, longitud y peso seco de las plántulas germinadas, durante el período de tiempo que permanecieron almacenadas y el tamaño de las semillas. Los resultados permitieron concluir que: i) el porcentaje germinativo de las semillas de pimienta-rosa almacenadas disminuyó a lo largo de los meses; ii) el contenido de humedad disminuyó durante los meses evaluados; iii) los diferentes tamaños de semilla no mostraron diferencias en la germinación y el tiempo de almacenamiento y iv) los valores de longitud y peso seco de las plántulas no difirieron según el período de almacenamiento.

Palabras clave: almacenamiento; germinación; conservación; calidad fisiológica; asentamiento agrícola.

\section{INTRODUCTION}

The main physiological function of seeds is to promote the perpetuation and multiplication of species. Therefore, to be considered a seed, it must be alive and be able to germinate and produce a new plant, as soon as it has favorable conditions for that (Melo, 2013). The germination and vigor test stand out among the tests used to measure the physiological viability of the seeds.

The germination test allows measuring the capacity of a seed to generate a new seedling with normal characteristics, while the vigor test allows estimating the potential performance of the seeds under field conditions (Guedes et al., 2015). According to the authors, the main tests that allow evaluating the performance of seedlings in field conditions are the first germination count, the germination speed index, the seedling length, and seedling dry mass.

The germinative capacity and vigor of a seed is linked to genetics, environmental maturation factors, and storage times. Regarding storage, sometimes, the planting of seeds that have reached their stage of maturation can be immediately unfeasible, and so that there is no loss of this seed, its storage is a viable alternative. As a result, studies on the physiological behavior of the seed related to storage must always be taken into consideration.

As the knowledge applied to forest seed storage techniques is limited, it is necessary to develop methodologies that preserve their physiological quality. According to Marcos Filho (2005), the longevity of the seeds varies according to the genotype, but the period of conservation of the physiological potential depends, in large part, on the humidity degree of the seeds and on the storage environment conditions. Regarding storage conditions, the external factors, relative humidity and air temperature, are fundamentally important.

In Brazil, the demand for seeds of native forest species has increased; however, according to Oliveira et al. (2018), its speed of deterioration has been very high. The authors point out that the period in which the viability can be maintained varies from a few weeks to a few months, showing the importance of research aimed at the storage of these species.

In relation to research involving the species of Schinus terebinthifolia Raddi, studies on the evaluation of the seeds physiological quality are fundamentally important since there is a 
significant increase in the demand for their fruits as food and industrial raw material, which makes the species promising to be grown in large-scale plantations.

Currently, Brazil is the world's largest producer of pink pepper fruits (Diegues, 2018), with most of the production coming from extraction. Due to the species of $S$. terebinthifolia having a wide distribution along the entire Brazilian coast, it is an alternative source of income for small fishing communities (Diegues, 2018 and Neves et al., 2016). For instance, the Ademar Moreira Settlement (RJ), which collectively reaps its fruits and is considered a pioneer in what concerns the sustainable extraction of the species in the State of Rio de Janeiro.

In their study on the interference of seed quality parameters in the sustainability of the Ademar Moreira Settlement (RJ), Rodrigues et al. (2020) recommend the adoption of best practices for harvesting, processing, and seeds storage. In this way, this work sought to evaluate the interference of the storage period in the physiological quality of pink pepper seeds, as it is made available by the settlement at the time of its commercialization.

\section{MATERIALS AND METHODS}

\section{Location of the seed harvesting area and} conducting the experiment. The seeds were obtained in June 2018, at the Ademar Moreira Rural Settlement located in the rural area of São Pedro da Aldeia - RJ municipality, whose coordinates are $-22.71390 \mathrm{~S}$ and $-42.10845 \mathrm{~W}$. The region's climate is classified as tropical, with an average annual temperature varying between 24 and $28^{\circ} \mathrm{C}$, with November/ December as the months of greatest precipitation and June/July the driest ones (Rodrigues et al., 2020).

The experiment was initially carried out at the Laboratório de Biologia Reprodutiva e Conservação de Espécies Arbóreas (LACON) and ended at the Luiz Fernando Oliveira Capellão Forest Nursery, both located at the Instituto de Florestas, of the Universidade Federal Rural do Rio de Janeiro. The seeds obtained were subjected to a set of sieves from the Tyler series, numbers: $3.5,4,5,6$, $7,8,10$ and bottom, corresponding to the following mesh openings: 5.6, 4.75, 4, 3.35, 2.8, 2.36, 2 and $0 \mathrm{~mm}$, in due order, with the purpose of obtaining homogeneous plots in terms of seed granulometry.

The analyzes were made with the seeds that were retained in the Tyler sieve 4 and 5 (meshes of 4.75 and $4 \mathrm{~mm}$, respectively). The experiment started in September 2018 and had a total duration of seven months. The water content, the length of the root, the shoot and seedling, and the respective dry mass were measured in the seeds in relation to the storage time, with germinated seedling count at ten and eighteen days after the installation of the germination test, according to the Instructions for Rules for the Analysis of Seeds of Forest Species (MAPA, 2013).

Evaluation of the physiological quality of seeds under the influence of storage Water content. The determination of the moisture content of the seeds was carried out at the time the seed lot was obtained (initial moisture), as well as during the germination tests in the field. This water content determination was carried out by the greenhouse method at 105 $\pm 3^{\circ} \mathrm{C}$ for $24 \mathrm{~h}$, according to the prescriptions of the Rules for Seed Analysis (MAPA, 2009). The result was obtained by applying the 
mathematical equation presented below, expressed as a percentage on the wet basis.

$$
U=\frac{100(P-p)}{P-t}
$$

Where:

$\mathrm{U}$ corresponds to the percentage of humidity in the wet basis (b.u.);

$\mathrm{P}$, the initial weight in grams (weight of the container, plus the weight of the wet seed, in grams);

$\mathrm{p}$, the final weight in grams (weight of the container, plus the weight of the dry seed, in grams); and

t, the tare weight (weight of the container, in grams).

It should be noted that after determining the initial moisture, knowing that the pink pepper seed resists low temperatures without losing its viability, and being unable to perform the test immediately; the seeds were taken to the refrigerator where they remained stored under a temperature of $11.7^{\circ} \mathrm{C}$ and a relative humidity of $55 \%$ for three months until the beginning of physiological tests (germination, length of seedlings and determination of dry mass).

Preliminary germination test. Preliminary tests were carried out at LACON in the months of September and October 2018 to assess the quality of seeds in the laboratory, aiming at future planting in the field. To conduct the test in question, eight 25-seed sub-samples were used, half of which were made up of $4.75 \mathrm{~mm}$ fruit seeds, and the other half were $4.0 \mathrm{~mm}$ fruit seeds previously treated according to asepsis recommendations for the species. Consequently, the seeds were arranged in gerbox boxes lined with two sheets of germitest paper moistened with water and kept in a B.O.D type chamber regulated at a temperature of $25^{\circ} \mathrm{C}$ (MAPA, 2013). The evaluations were carried out at seven and fourteen days after sowing (DAS).

Field germination test. Field evaluations took place at the UFRRJ Forest Nursery facilities, from November 2018 to April 2019. Due to the limited quantity of seeds, the sample was divided into four sub-samples of 50 seeds; half consisted of $4.75 \mathrm{~mm}$ fruit seeds, and the other part of $4.0 \mathrm{~mm}$ fruit seeds.

The seeds were accommodated in plastic boxes with the sand as substrate and covered with a thin layer of vermiculite. Measurements were made at ten and eighteen days after sowing (DAS), as recommended for the species (MAPA, 2013). Asepsis treatment was not applied.

The evaluations took place at ten and eighteen days after the installation of each test, considering as normal seedling those that presented their essential structures well developed, complete, proportional, and healthy. The results were expressed as a percentage.

First germination count. The first germination count was conducted together with the germination test, with the first count being performed ten days after sowing. The results were expressed as a percentage (\%).

Root length, shoot, and total seedling length. The measurements related to the length of the root, shoot, and the total length of the seedlings were carried out concurrently with the germination test with the use of a caliper. The results were expressed in millimeters (mm). 
Dry mass of seedlings. The determination of the dry mass of the seedlings also occurred together with the germination test. After harvesting the seedlings, the activity was continued by collecting and accommodating them in Kraft paper bags, and then directing them to drying in the oven regulated at $80^{\circ} \mathrm{C}$ for 24 hours. After 24 hours, the seedlings were weighed on an analytical balance with an accuracy of 0.0001 and the respective results were expressed in grams (g).

Statistical analysis. The experimental design used in the evaluation of data referring to the first count and percentage of germination was a $2 \times 6$ factorial (two meshes and 6 months). However, in relation to the measurements made regarding the length of the shoot, length of the root, and length of the seedling, as well as the dry weight of the same, the analysis was performed by means of a 2 x 5 factorial (two meshes and 5 months). The means were compared using the Tukey test at 5\% significance with the aid of the Sisvar program. The germination data were transformed into a sine $\operatorname{arc} \sqrt{\mathrm{x}} / 100$.

\section{RESULTS AND DISCUSSION}

\section{Initial moisture content and preliminary}

test result. At the reception of the seed lot, the water content of the material was analyzed, and the value obtained was $20.75 \%$. In the preliminary tests carried out, there was no occurrence of seedling emergence, being observed an eventual fungal growth, which may possibly be linked to the way in which the stages of harvesting, processing, and storage of the seeds proceeded. This condition motivated the change in the conduct of the experiment, subjecting it to field conditions since it was found fungi that would be masking the germinative potential of the sampled seeds. According to Pinto et al. (2012), during storage, the high degree of humidity is one of the biggest causes of seed germination loss as it provides conditions for the appearance of fungi that contribute to the decrease of its viability.

\section{Evaluation of the physiological quality of seeds under the influence of storage}

Germination test and first count. In the present work, the field experiment took place five months (November) after harvesting the fruits, being concluded when they complete ten months (April) of their submission to the storage conditions. It was observed that $S$. terebinthifolia Raddi seeds arising from both fruits $4.75 \mathrm{~mm}$ fruit and those $4.0 \mathrm{~mm}$ fruit did not present satisfactory germinative percentages in the first month of analysis; however, these results configured the best germination indexes in comparison to the other evaluated months. Subsequently, both showed a decrease in seedling emergence over the months in which the analyzes were carried out (Figure 1).

The results of the average germination percentage, first count and water content of the pink pepper seeds obtained during the storage period evaluated are shown in Table 1. 


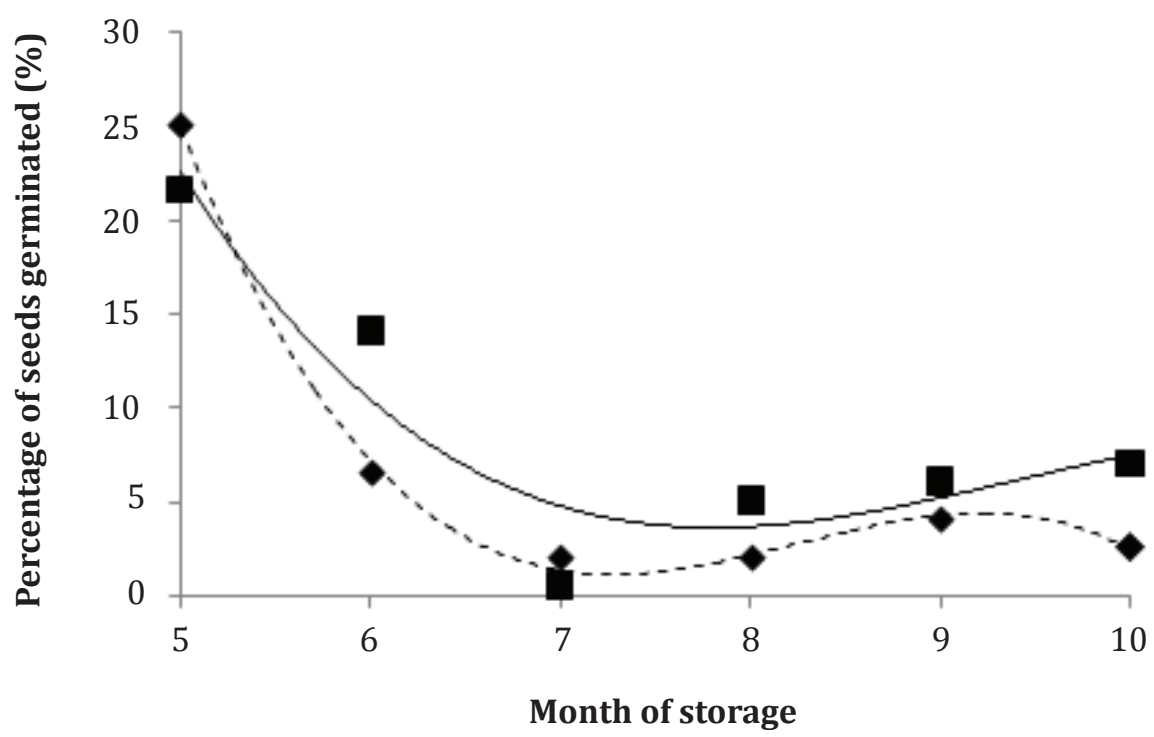

Figure 1. Regression curve of the average germination data of the pink pepper seeds (Schinus terebinthifolia Raddi) from the $4.75 \mathrm{~mm}(\diamond)$ and 4.0mm (घ) sieves, stored for 5, 6, 7, 8, 9 and 10 months.

Table 1. Average data of water content (U\%), first count (PC\%) and germination (G\%) of pink pepper seeds from sieve sizes of 4.0 and $4.75 \mathrm{~mm}$, stored for $5,6,7,8,9$ and 10 months.

\begin{tabular}{ccccccc}
\hline & \multicolumn{2}{c}{ U (\%) } & \multicolumn{2}{c}{ PC (\%) } & \multicolumn{2}{c}{ G (\%) } \\
\cline { 2 - 7 } Month & Granul. & Granul. & Granul. & Granul. & Granul. & Granul. \\
& $4.75 \mathrm{~mm}$ & $4.0 \mathrm{~mm}$ & $4.75 \mathrm{~mm}$ & $4.0 \mathrm{~mm}$ & $4.75 \mathrm{~mm}$ & $4.0 \mathrm{~mm}$ \\
\hline 5 & 20.50 & 20.50 & - & - & $25 \mathrm{Aa}$ & $21.5 \mathrm{Aa}$ \\
6 & 16.43 & 16.43 & $6 \mathrm{Aa}$ & $12 \mathrm{Aa}$ & $6.5 \mathrm{Ba}$ & $14 \mathrm{ABa}$ \\
7 & 16.43 & 16.43 & $0 \mathrm{Aa}$ & $0 \mathrm{Ba}$ & $2 \mathrm{Ba}$ & $0.5 \mathrm{Ca}$ \\
8 & 12.62 & 14.23 & $0 \mathrm{Aa}$ & $0 \mathrm{Ba}$ & $2 \mathrm{Ba}$ & $5 \mathrm{BCa}$ \\
9 & 10.99 & 11.66 & $4 \mathrm{Ab}$ & $11 \mathrm{Aa}$ & $4 \mathrm{Ba}$ & $6 \mathrm{BCa}$ \\
10 & 10.36 & 11.46 & $0 \mathrm{Aa}$ & $1 \mathrm{Ba}$ & $2.5 \mathrm{Ba}$ & $7 \mathrm{BCa}$ \\
CV & & & \multicolumn{2}{c}{73.65} & \multicolumn{2}{c}{46.60} \\
\hline
\end{tabular}

Granul. (granulometry). CV (coefficient of variation). Averages followed by the same lowercase letter on the line (granulometry) and the same uppercase letter on the column (months), do not differ significantly by the Tukey test at the $5 \%$ probability level.

Statistically analyzing the physiological responses presented by the pink pepper seeds during the storage period, it can be inferred that: regarding fruits with a size of $4.75 \mathrm{~mm}$, the percentage of germination occurred in the first month of the experiment (November) and the respective five months of storage, is significantly higher than that presented in the other months, constituting the best germinal index. 
It was observed that the advance of the storage period culminated in low percentages of germination with no significant difference between the months of December to April, showing a compromise in the viability of the seeds to the detriment of the increase in the storage period. The behavior presented by the seeds corresponding to the $4.0 \mathrm{~mm}$ granulometry fruits is similar to that previously described; however, the reduction in the germinative percentage occurs more slowly, reaching the most critical stage in January and a punctual increase in the percentage of germinated seeds in the later months. No significant difference was detected in the interval between February and April, equivalent to the period from eight to ten months of seed storage, respectively.

The distribution of germination over the period in which the lot remained under proper storage conditions agrees with the physiological response found by Ribeiro et al. (2018), where after six months of storage of S. terebinthifolia Raddi seeds, they observed losses in the quality of seeds of the species.

Regarding the mesh size of the sieves, there was no significant difference between the pink pepper seeds of different sieves, not pointing the seed size as a conditioning factor to obtain a higher germination rate for the species. Regarding the species $S$. terebinthifolia Raddi, studies that explore the possible relationship between seed size and physiological quality of the same are uncommon; however, Vitória et al. (2018) attributed superiority to those extracted from ripe fruits.
It is noted that the reduction of the germinative percentage in the seeds of fruits of $4.0 \mathrm{~mm}$ size is slower than in the seeds of fruits of $4.75 \mathrm{~mm}$ size; however, both had a drastic reduction in the month of January, equivalent to the third month of field experiment and respective seven months of storage. This drastic reduction may be related to climatic factors because when seen in Figure 2, the month of January had the lowest precipitation and the highest temperature, which may have inhibited the germination of the seeds. The climatic data related to the period comprising the sequence of analyzes are shown in Figure 2.

It is possible to observe that the month of January is characterized by the record of the highest averages of temperature, both maximum and minimum, combined with the lowest averages of relative humidity of the air and precipitation, configuring a hot and dry month. After this, a gradual reduction in the average temperature values is observed accompanied by an increase in the relative humidity of the air.

Concerning thesevariations, there was a small increase in the percentage of germinated seeds corresponding to the seeds extracted from the $4.0 \mathrm{~mm}$ granulometry fruits, also observed in the following months. However, the same is not true in the seeds corresponding to the $4.75 \mathrm{~mm}$ granulometry fruits since in this case, a stationary pattern is observed first, and only then an increase of a slower nature, in comparison to the smaller seeds. 

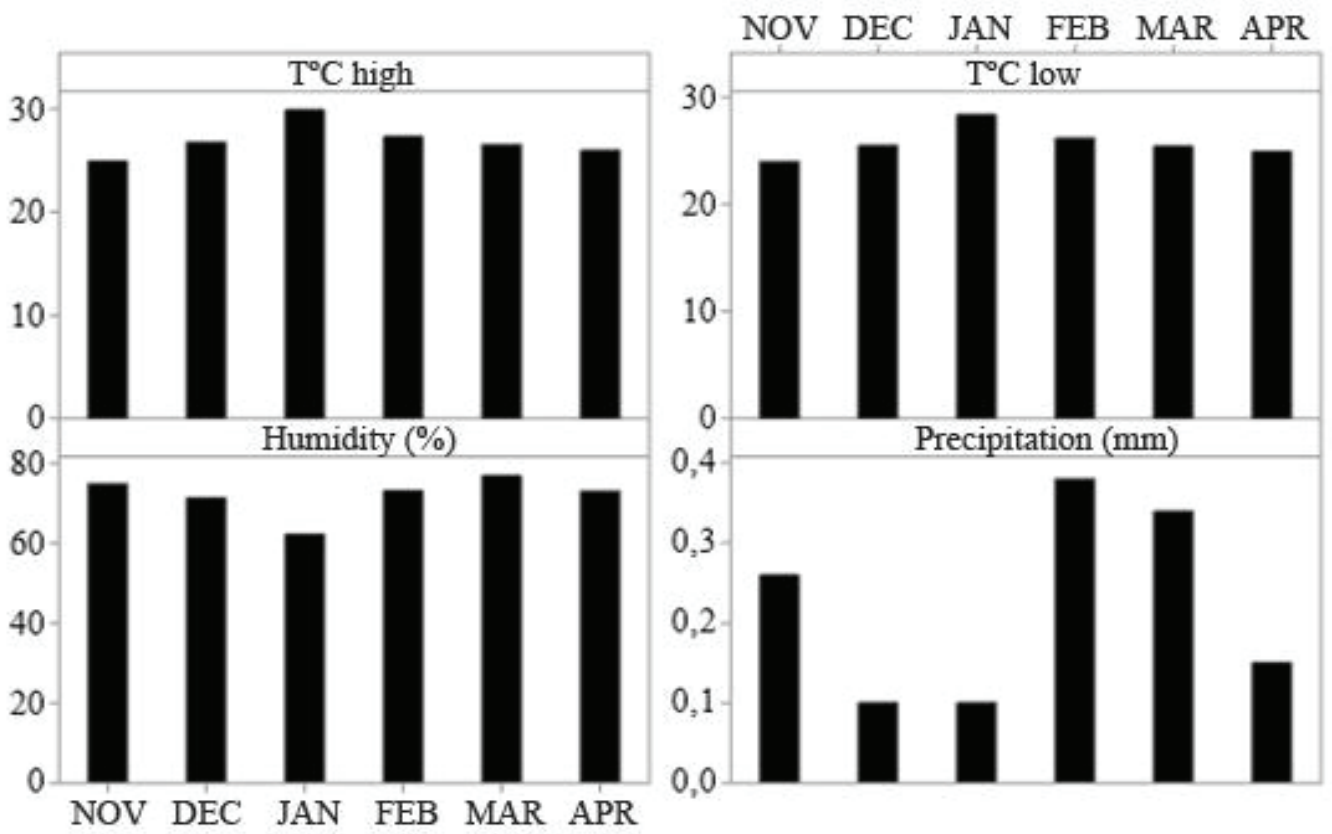

Figure 2. Average data of maximum temperature $\left(\mathrm{T}^{\circ} \mathrm{C}\right.$ max $)$, minimum temperature $\left(\mathrm{T}^{\circ} \mathrm{C} \mathrm{min}\right)$, relative humidity of the air ( $\mathrm{RH}(\%)$, and precipitation - ppt $(\mathrm{mm})$ during the months of November and December 2018, and January, February, March, and April 2019.

It is known that temperature variations have an influence on the development of plant species such as on the germination process, with ranges in which germination may not occur. According to the results obtained by Vitória et al. (2018), constant temperatures of $30^{\circ} \mathrm{C}$ and alternating temperatures of 20 to $30^{\circ} \mathrm{C}$ favored the germination and vigor of the seeds of $S$. terebinthifolia Raddi. Whereas Velasques et al. (2015) recommend a temperature of $25^{\circ} \mathrm{C}$. It is worth mentioning that both works were conducted in the laboratory.

According to Marcos Filho (2005), variations in temperature affect the speed, percentage, and uniformity of germination. The author also notes that in the absence of other limiting factors, germination occurs relatively under wide temperature limits. However, in this work, the extension of the seed storage time and the consequent triggering of deterioration processes, which cannot now be avoided, have been added to this factor.

One of the explanatory causes for the occurrence of reduction in germination after the extension of the storage period is the negative action of the moisture existing in the seed. It is possible to observe (Table 1 and Figure 3) that the water content presented by the seed lot is initially high. It was not possible to perform the statistical procedure for this parameter due to the insufficient number of repetitions used; however, it is possible to notice that its reduction in the water content of the seeds occurs gradually over the storage time, in both sizes. 


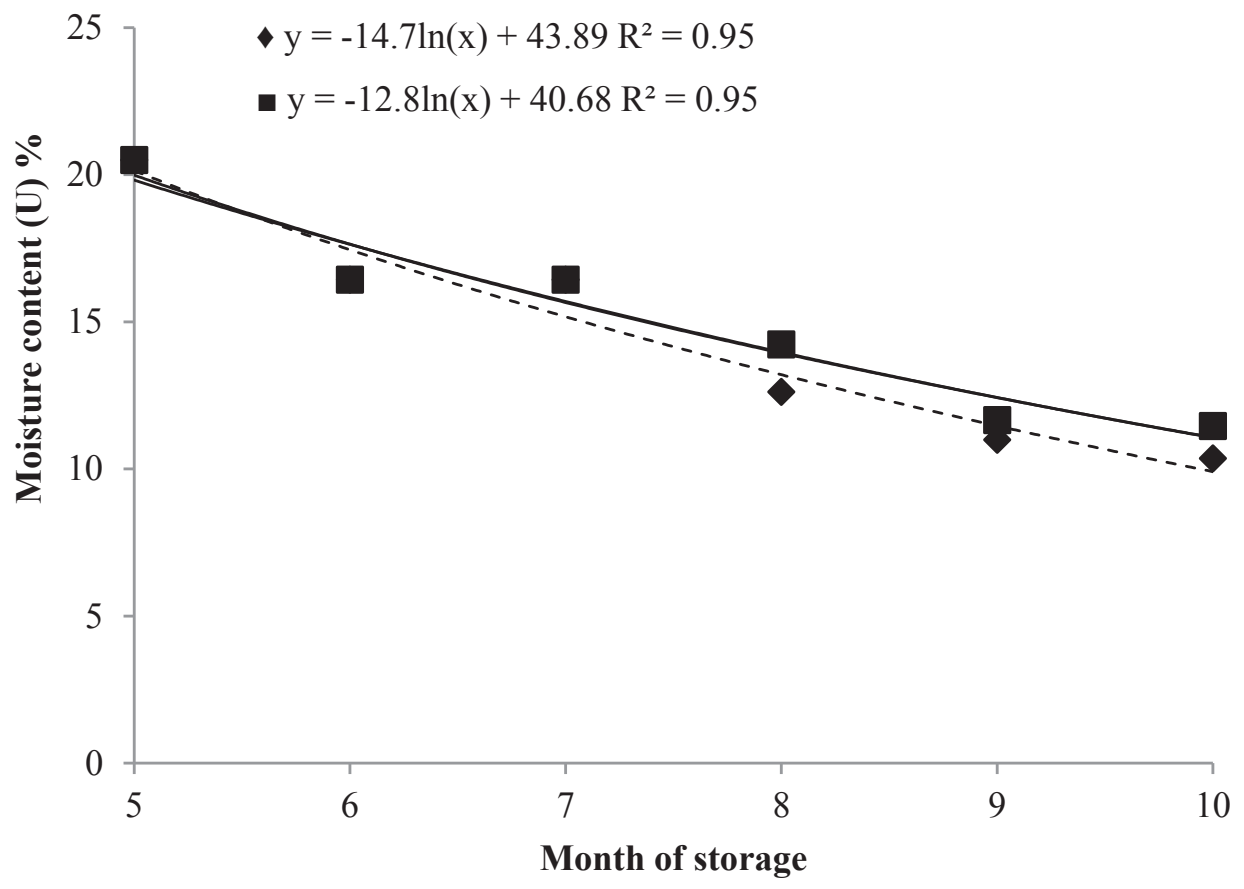

Figure 3. Regression curve of the average data referring to the moisture content of the pink pepper seeds (Schinus terebinthifolia Raddi) of the sieves of size $4.75 \mathrm{~mm}$ $(\diamond)$ and $4.0 \mathrm{~mm}(\mathbf{\square})$, stored for 5, 6, 7, 8, 9 and 10 months.

As it is an orthodox species, it is understood that traditional drying methods do not cause damage; however, no procedure was performed in this sense since it was intended to know the behavior of the seeds under the conditions that are commercialized in the settlement.

According to the data presented, even though there was a reduction in the water content over the storage period, the percentage remained in the range that contributes to the appearance of depreciating conditions. Given the above, it is noted that this condition may have influenced the low expression of the germinative potential presented by the lot in the first months of the experiment.

Oliveira et al. (2018) found a certain stabilization in the germination results during the four months that the $S$. terebinthifolia
Raddi seeds remained stored in refrigerator conditions, and it was also observed that the germination speed of the seeds decreased with the increase of the storage time, suggesting, therefore, the beginning of the loss of vigor.

The number of seedlings at the time of the first count of the germination test comprised low values with zero seedlings in the months of January and February, corresponding to the highest average values of temperature, in both seed sizes, with no statistical difference between them as well as between the months evaluated, Figure 4. These results agree with what Oliveira et al. (2018) suggest, since supported by the principle of this verification, it is understood that the samples with the highest percentage of normal seedlings at the time of the first germination count are the most vigorous. 


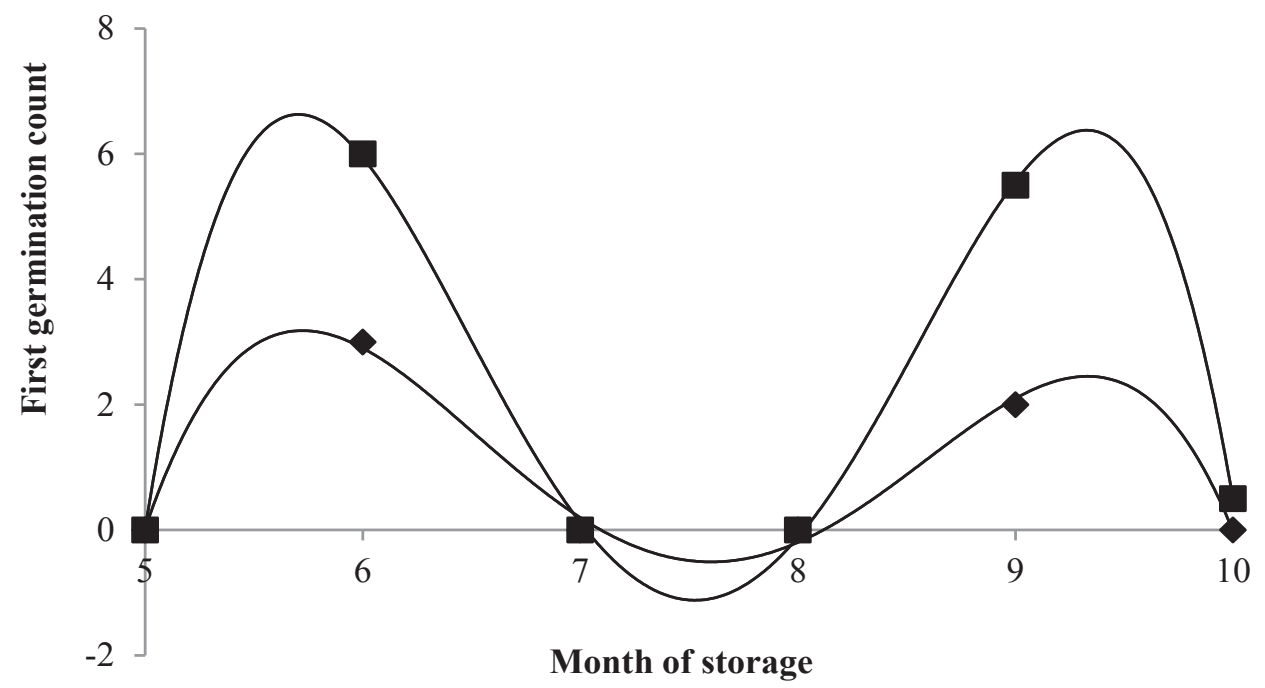

Figure 4. Regression curve of the average data of the first germination count of the pink pepper seeds (Schinus terebinthifolia Raddi) from sieves of $4.75 \mathrm{~mm}$ $(\checkmark)$ and $4.0 \mathrm{~mm}(\mathbf{m})$, stored for 5, 6, 7, 8, 9 and 10 months.

Root length, shoot, total length, and dry mass of seedlings. The length of the shoot, length of the root, and length of the seedling (Table 2), there were no statistical differences over the months in that the measurements were carried out. Not even seeds of bigger $(4.75 \mathrm{~mm})$ were a conditioning factor for obtaining larger seedlings for the species.
According to Diegues (2018), the female genotypes of the species present a great genotypic diversity, thus, the high coefficients of variation found can be attributed to this characteristic. The variation in the length of roots, shoots and total length of seedlings as a function of storage time is shown in Figure 5 (A, B and C).

Table 2. Length of shoot (PA), length of root (CR), total length of seedlings (CTP), and dry weight of seedlings (PSP) of pink pepper (Schinus terebinthifolia Raddi.) harvested during the months of December 2018 to April 2019.

\begin{tabular}{ccccc}
\hline & \multicolumn{2}{c}{ PA (mm) } & \multicolumn{2}{c}{ CR (mm) } \\
\cline { 2 - 5 } Month & Granulometry & Granulometry & Granulometry & Granulometry \\
& $4.75 \mathrm{~mm}$ & $4.0 \mathrm{~mm}$ & $4.75 \mathrm{~mm}$ & $4.0 \mathrm{~mm}$ \\
\hline 6 & $15.70 \mathrm{Aa}$ & $17.50 \mathrm{Aa}$ & $13.35 \mathrm{Aa}$ & $14.77 \mathrm{Aa}$ \\
7 & $15.90 \mathrm{Aa}$ & $13.65 \mathrm{Aa}$ & $9.21 \mathrm{Aa}$ & $7.30 \mathrm{Aa}$ \\
8 & $20.60 \mathrm{Aa}$ & $20.97 \mathrm{Aa}$ & $14.87 \mathrm{Aa}$ & $10.92 \mathrm{Aa}$ \\
9 & $17.81 \mathrm{Aa}$ & $18.34 \mathrm{Aa}$ & $25.62 \mathrm{Aa}$ & $15.81 \mathrm{Aa}$ \\
10 & $15.33 \mathrm{Aa}$ & $14.25 \mathrm{Aa}$ & $14.72 \mathrm{Aa}$ & $25.36 \mathrm{Aa}$ \\
\hline $\mathrm{CV}$ & \multicolumn{3}{c}{79,79} \\
\hline
\end{tabular}


Continuation Tabla 2.

\begin{tabular}{ccccc}
\hline & \multicolumn{2}{c}{ CTP $(\mathbf{m m})$} & \multicolumn{2}{c}{ PSP (g) } \\
\cline { 2 - 5 } Month & $\begin{array}{c}\text { Granulometry } \\
\text { 4.75 mm }\end{array}$ & $\begin{array}{c}\text { Granulometry } \\
\text { 4.0 mm }\end{array}$ & $\begin{array}{c}\text { Granulometry } \\
4.75 \mathrm{~mm}\end{array}$ & $\begin{array}{c}\text { Granulometry } \\
4.0 \mathrm{~mm}\end{array}$ \\
\hline 6 & $29.04 \mathrm{Aa}$ & $32.27 \mathrm{Aa}$ & $0.03 \mathrm{Aa}$ & $0.06 \mathrm{Aa}$ \\
7 & $25.11 \mathrm{Aa}$ & $20.95 \mathrm{Aa}$ & $0.01 \mathrm{Aa}$ & $0.00 \mathrm{Aa}$ \\
8 & $37.48 \mathrm{Aa}$ & $29.65 \mathrm{Aa}$ & $0.03 \mathrm{Aa}$ & $0.05 \mathrm{Aa}$ \\
9 & $43.43 \mathrm{Aa}$ & $34.15 \mathrm{Aa}$ & $0.02 \mathrm{Aa}$ & $0.04 \mathrm{Aa}$ \\
10 & $30.04 \mathrm{Aa}$ & $39.61 \mathrm{Aa}$ & $0.02 \mathrm{Aa}$ & $0.03 \mathrm{Aa}$ \\
\hline CV & \multicolumn{3}{c}{32.36} \\
\hline
\end{tabular}

$\mathrm{CV}$ (coefficient of variation). Averages followed by the same lowercase letter in the row and the same uppercase letter in the column, do not differ significantly by the Tukey test at the level of $5 \%$ probability.

A)

$$
\begin{aligned}
& y=-1,057 x 3+24,72 x 2-190,3 x+496,5 R^{2}=0,62 \\
& y=-2,782 x 3+65,39 x 2-503,4 x+1284, R^{2}=0,77
\end{aligned}
$$

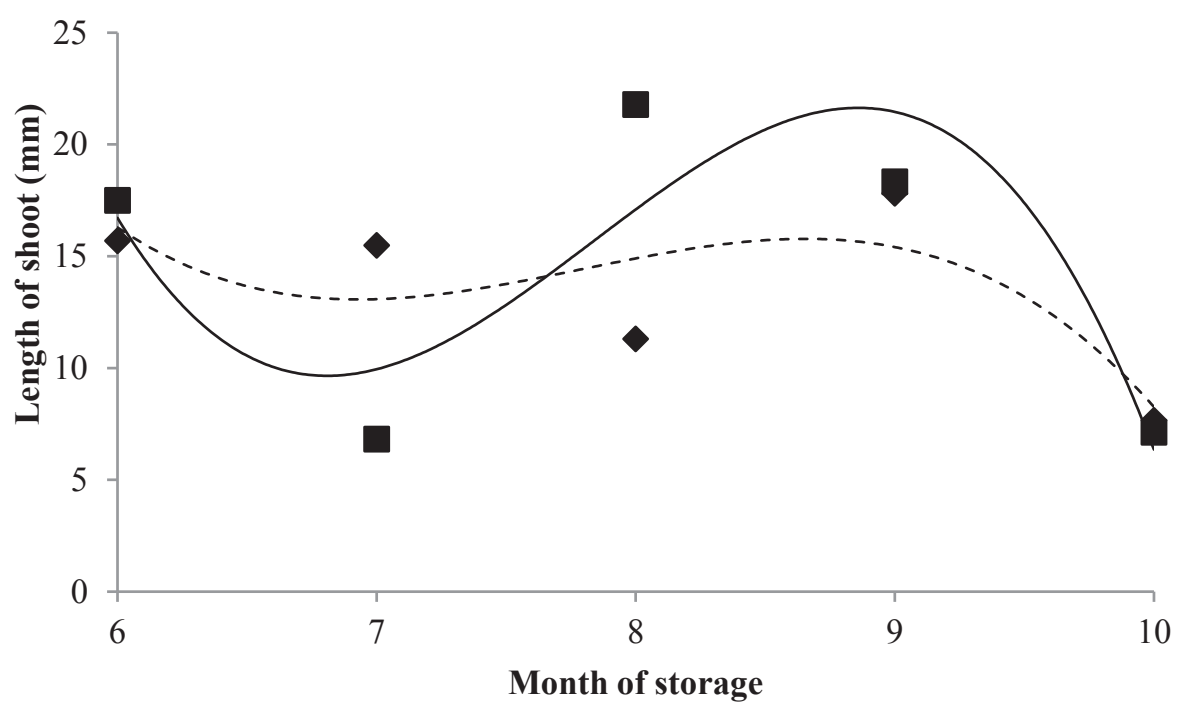


B)

$\mathrm{y}=-3.060 \mathrm{x} 3+72.79 \mathrm{x} 2-566.2 \mathrm{x}+1452 . \mathrm{R}^{2}=0.62$

- $y=-2.200 x 3+53.51 x 2-425.3 x+1115 . R^{2}=0.89$

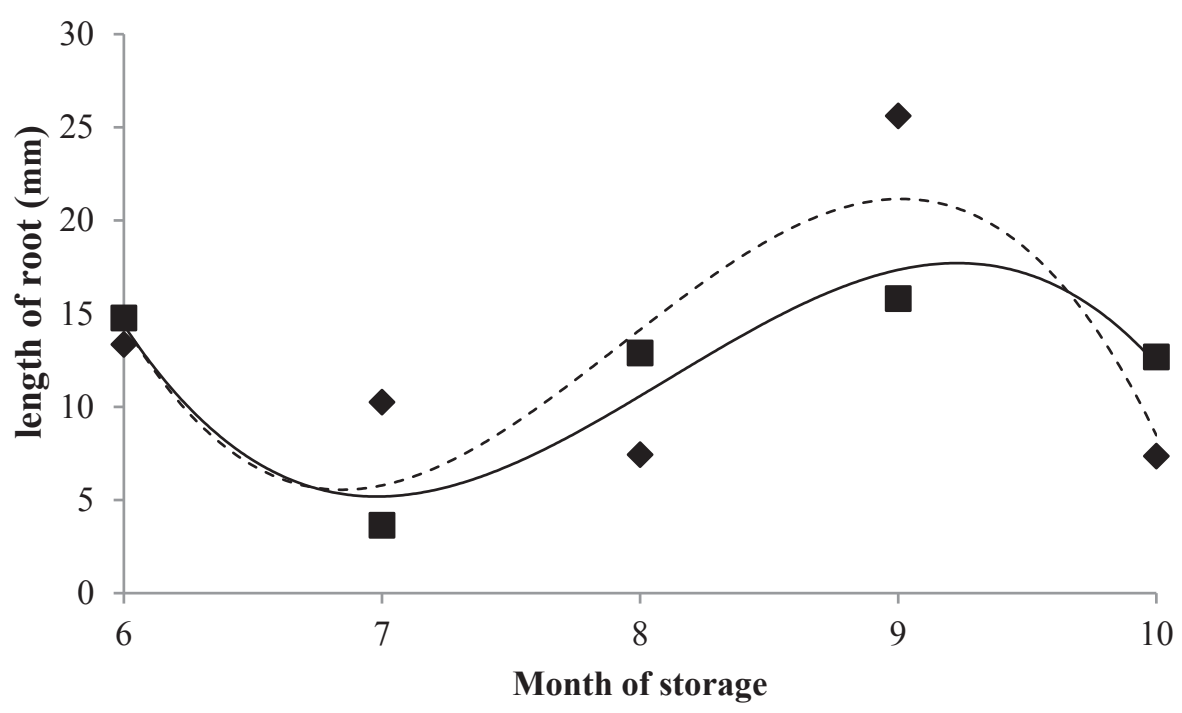

C)
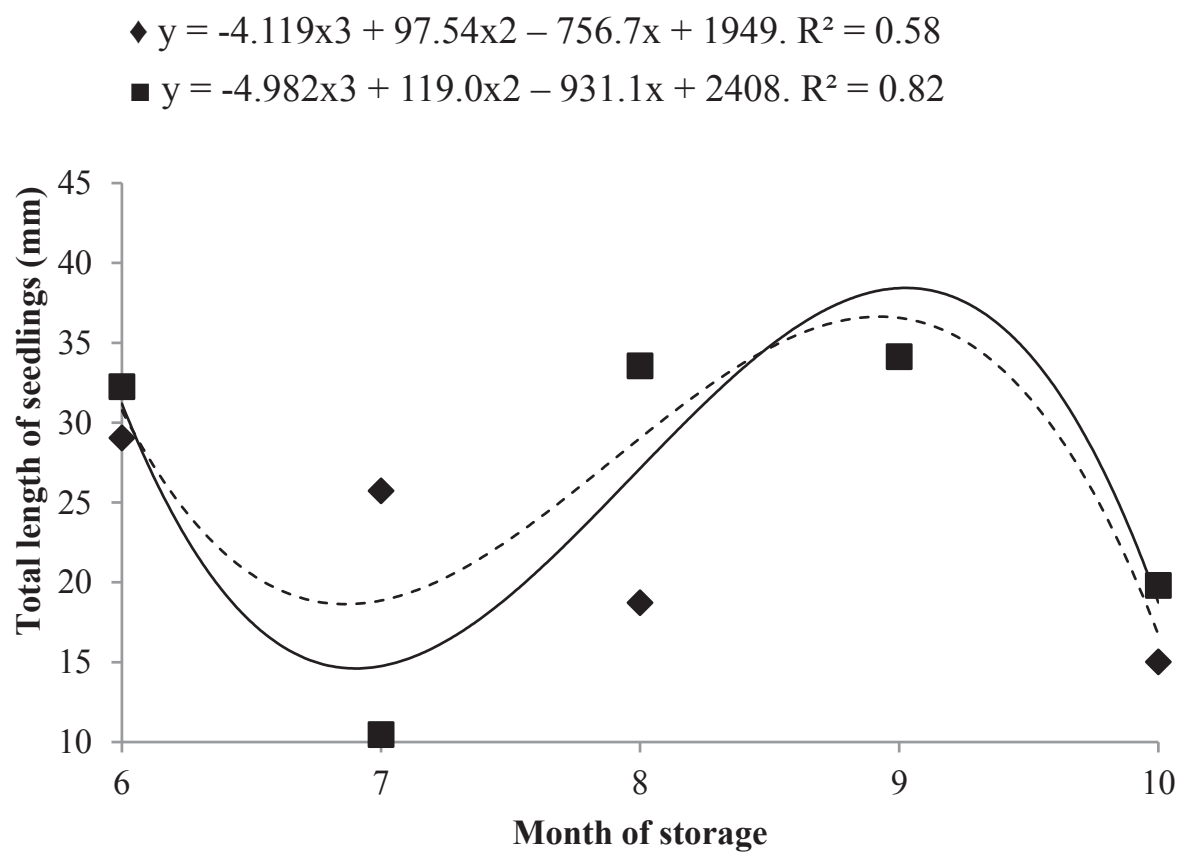

Figure 5. (A) Regression curve of the average data concerning the length of the shoot of the seedlings. (B) Regression curve of the average data referring to the length of the root of the seedling, and (C) Regression curve of the average data referring to the total length of seedlings of pink pepper (Schinus terebinthifolia Raddi) originating from seeds of sieves of size $4.75 \mathrm{~mm}(\bullet)$ and $4.0 \mathrm{~mm}(\mathbf{*})$, stored for 6, 7, 8, 9 and 10 months. 
Numerically analyzing the results of the evaluated parameters, it is clear that frequently, the most expressive values were reached when the temperature was close to the value considered as optimal for the species in question, comprising the months of February, March, and April, whose average temperatures were 26.79, 26.04 and $25.5^{\circ} \mathrm{C}$. The temperature peak is reached in the month of January, whose average value is $29.17^{\circ} \mathrm{C}$; this condition culminates in the shortest root lengths.

The presented physiological responses do not corroborate the common idea that larger seeds originate seedlings of greater size and mass since according to Table 2, no statistical differences were found for this parameter over the evaluated months, as well as there was no significant variation between seeds of different sizes for the species in question.

Regarding the dry mass of seedlings over the evaluated period, the same tendency for germination and seedling can be observed; that means, it was higher in November, decreased in January and February, and increased between March and April, (Figure 6).

\section{CONCLUSIONS}

Among the analyzed parameters of physiological quality, the germinative percentage of the stored pink pepper seeds and moisture content decreased over the evaluated months.

The percentage of germination and the length of the seedlings did not differ in function to the seed granulometry.

The seedling length and dry weight values did not differ according to the storage period.

Conflict of interest: The authors declare that there is no conflict of interest.

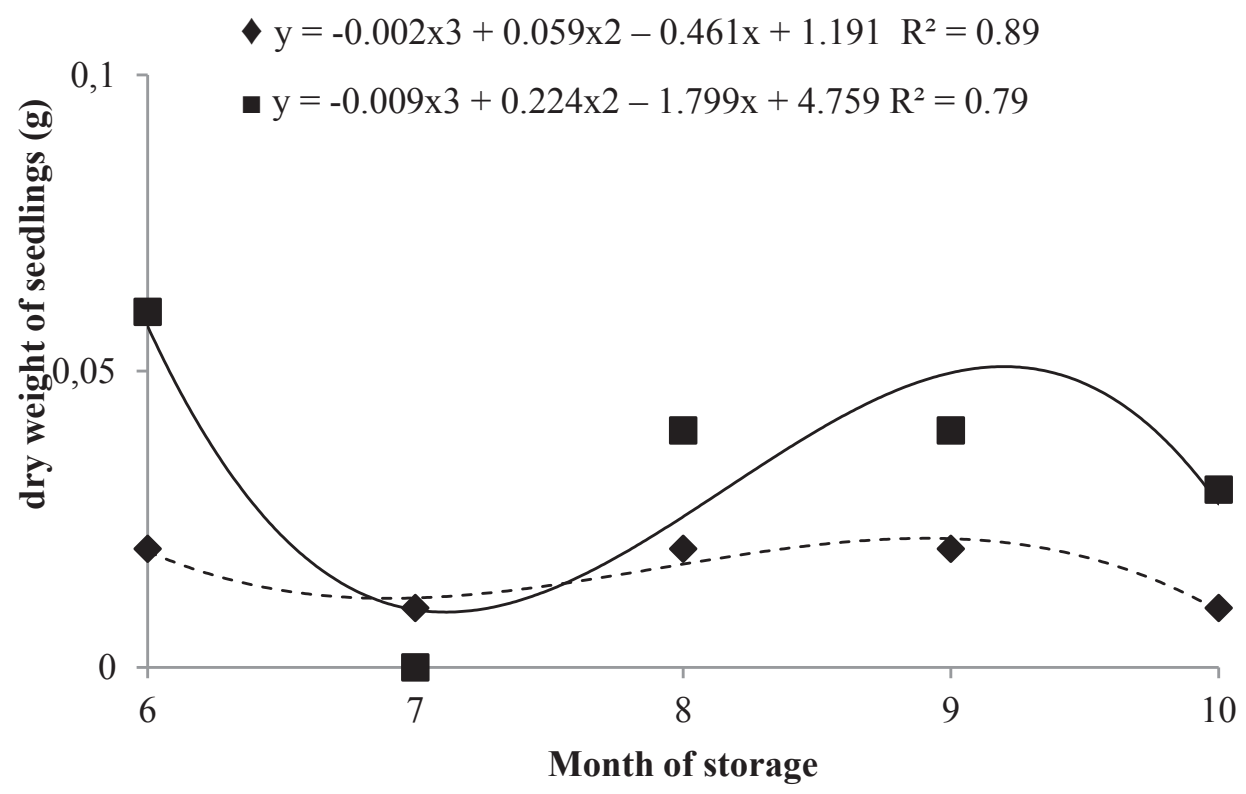

Figure 6. Regression curve of the average data of dry weight of seedlings of pink pepper seeds (Schinus terebinthifolia Raddi) from sieves of size 4.75 and $4.0 \mathrm{~mm}$. 


\section{BIBLIOGRAPHIC REFERENCES}

Diegues, I. P. (2018). Diversidade genética em aroeira (Schinus terebinthifolius Raddi) com base em aspectos morfoagronômicos, moleculares e químicos. Retrieved from https://ri.ufs.br/bitstream/riufs/6621/1/ DANILLA_CRISTINA_LEMOS_SOUZA.pdf

Guedes, R. S.; Alves, E. U.; Santos-Moura, S. S.; Galindo, E. A. (2015). Teste de comprimento de plântula na avaliação da qualidade fisiológica de sementes de Amburana cearensis (Allemão) A. C. Smith. Semin. Cienc. Agrar. 36 (4): 23732382. doi: https://doi.org/110.5433/1679$0359.2015 v 36 n 4 p 2373$

MAPA- Ministério da Agricultura, Pecuária e Abastecimento. (2009). Regras para análise de sementes. Brasília: MAPA/ACS. 399p.

MAPA - Ministério da Agricultura, Pecuária e Abastecimento. (2013). Instruções para análises de sementes de espécies florestais. Brasília: MAPA. 98p.

Marcos Filho, J. (2005). Fisiologia de sementes de plantas cultivadas. Piracicaba: FEALQ. 495p.

Melo, P. C. T. (2013). Sementes comestíveis. Agrollink. Retrieved from https://cutt.ly/ ObXEZoS

Neves, E. J. M.; Santos, A. M.; Gomes, J. B. V.; Ruas, F. G; Ventura, J. A. (2016). Cultivo da aroeiravermelha (Schinus terebinthifolius Raddi.) para produção de pimenta-rosa. Colombo: Embrapa Florestas. 24p.

Oliveira, F. T. G.; Vitória, R. Z.; Posse, S. C. P.; Arantes, S. D.; Schmildt, O.; Viana, A.; Malikouski, R. G; Barros, B. L. A. (2018). Qualidade fisiológica de sementes de aroeira em função das condições de armazenamento. Nucleus. 15 (2): 567-574. doi: https://doi. org/10.3738/1982.2278.2959

Pinto, J. V. C; Poleto, G. V.; Kato, E. M.; Vieira, M. C.; Heredia Zárate, N. A.; Bottega, S. P.; Rech J. (2012). Germinação, umidade e quebra de dormência em sementes de Schinus terebinthifolius Raddi. Hortic. Bras. 30 (2): S6253-S6258.

Ribeiro, L. P.; Leite Filho, A. T.; Silva, L. B. J.; Silva, V. F.; Lima e Borges, E. E. (2018). Physiological and biochemical changes in brazilian pepper (Schinus terebinthifolius Raddi.) seeds during storage. Viçosa: Rev. Arvore, 42 (1): e420105. doi: http://dx.doi. org/10.1590/1806-90882018000100005

Rodrigues, A.; Palermo, G.; Braz, M.; Tiago, B. (2020). Quality parameters of pink pepper seeds as sustainability indicators. Revista de Ciencias Agrícolas. 37(2): 27-39. doi: https:// doi.org/10.22267/rcia.203702.135

Velasques, N. C.; Cardoso, J. H.; Costa, C. J.; Guedes, R. S. (2015) Germinação de sementes Schinus terebinthifolius Raddi. Retrieved from https:// cutt.ly/LbXfVjj

Vitória, R. Z.; Oliveira, F. T. G.; Posse, S. C. P.; Arantes, S. D.; Schmildt, O.; Viana, A.; Malikouski, R. G.; Barros, B. L. A. (2018). Qualidade fisiológica de sementes de aroeira em função da maturação dos frutos sob diferentes temperaturas de germinação. Nucleus. 15 (2): 575-582. doi: http://dx.doi. org/10.3738/1982.2278.2870 